\title{
Isolation and Characterization of Microbial Strains with Hydrolytic Enzyme Profile from Clay Minerals
}

\author{
Sulhee Lee ${ }^{1 \dagger}$, Eui-Sang $\mathrm{Cho}^{2 \dagger}$, Young-Do Nam ${ }^{1}$, So-Lim Park ${ }^{1}$, Seong-Il Lim ${ }^{1}$, Dong-Ho Seo ${ }^{3}$, Jae-Hwan Kim ${ }^{4 *}$, and \\ Myung-Ji Seo ${ }^{2,5 *}$ \\ ${ }^{1}$ Research Group of Healthcare, Korea Food Research Institute, Wanju 55365, Republic of Korea \\ ${ }^{2}$ Department of Bioengineering and Nano-Bioengineering, Graduate School of Incheon National University, Incheon 22012, Republic of Korea \\ ${ }^{3}$ Department of Food Science and Technology, College of Agriculture and Life Sciences, Jeonbuk National University, Jeonju 54896, Republic \\ of Korea \\ ${ }^{4}$ Advanced Geo-materials Research Department, Pohang Branch, Korea Institute of Geoscience and Mineral Resources, Pohang 37559, \\ Republic of Korea \\ ${ }^{5}$ Division of Bioengineering, Incheon National University, Incheon 22012, Republic of Korea
}

Received: October 30, 2019 / Revised: November 11, 2019 / Accepted: November 12, 2019

\begin{abstract}
A total of 262 bacterial strains were isolated from clay minerals, bentonite and zeolite, in Gyeongsangbukdo, Republic of Korea, and their hydrolytic enzyme activities were analyzed. Most of the isolated strains belonged to Micrococcales and Bacillales order. Of strains, 96 strains produced $\alpha$-amylase activity, 42 strains showed cellulase activity, 111 strains had pectinase activity, and 70 strains showed protease activity. Among them, 177 isolates exhibited one or more of the hydrolytic enzyme activities and in particular Bacillus cereus MBLB1321, B. albus MBLB1326 and KIGAM017, B. mobilis MBLB1328, MBLB1329 and MBLB1330 showed all of the enzyme activities. These results demonstrate the diversity of functional Bacillus species in clay minerals as vital sources for the discovery of industrially valuable hydrolytic enzymes, which have a great commercial prospect in various bio-industrial applications.
\end{abstract}

Keywords: Clay mineral, microorganism, hydrolytic enzyme, isolation

Clay mineral is derived from the Earth's surface layer and it has been used for a long time for various purposes such as agriculture, engineering, environmental application, geology, pharmaceutical, and construction [1-3]. They are defined to phyllosilicate minerals and/or to minerals which conduct plasticity to clay and which stiffen upon drying or firing [4]. The clay minerals,

\section{*Corresponding authors}

J.-H. K.

Tel: +82-54-245-3743, Fax: +82-54-245-3759

E-mail: jaehwankim@kigam.re.kr

M.-J. S.

Tel: +82-32-835-8267, Fax: +82-32-835-0804

E-mail: mjseo@inu.ac.kr

${ }^{\dagger}$ These authors contributed equally to this work

○ 2020, The Korean Society for Microbiology and Biotechnology which include iron, alkali metals, alkaline earths, and other cations, are existent in the lattice structure or in the interlayer space [3]. Clay minerals also have been studied for the improvement of geophagy and gastrointestinal disorder, and elimination of aflatoxin for animals [5].

Zeolite is clay mineral and classified as 'safe for human consumption' by FDA [6]. It contains high concentrations of magnesium, potassium, calcium, and sodium, which is in the tectosilicate class [7]. Zeolite is used as ion exchanger, separation agents, and adsorbents for industrial applications and mycotoxin and odor control, and livestock feed additives for agriculture [8]. Zeolite shows a growth inhibition against pathogens, such as Escherichia coli, Streptococcus mutans, Staphylococcus aureus, and Candida albicans [9]. It is reported 
that synthetic zeolite accelerated ethanol fermentation of sugarcane molasses by Saccharomyces cerevisiae [10]. Bentonite is clay mineral, which is a dominant source of montmorillonite in nature and it contains various ions such as aluminum, sodium, potassium, and calcium [11]. Because of the mineral composition of bentonite, it has various properties that sorbent effects, high dry bonding strength, impermeability, very low hydraulic conductivity, and high swelling capacity [11]. Especially, the roles of bentonite are an adsorbent of pathogens, toxins, and enzymes as a binding agent, and it enhances the health benefit and growth of the animals [2]. In previous study, the microflora of bentonite-treated kimchi was analyzed, bentonite affected bacterial diversity during fermentation. In addition, increased diversity in microbial community had also affected flavor aspects of kimchi [12]. As a result, the clay minerals are considered to have a significant effect on the diversity of microorganisms.

Although there have been lots of studies on physiological characteristics and biological activities of clay minerals themselves [13], there are not much data published on the isolation of microorganisms from clay minerals and evaluation of their physicochemical activities. In this study, we isolated microorganisms from domestic clay minerals, zeolites and bentonite to investigate cultivable microbial diversity and also evaluated their hydrolytic enzyme activities such as cellulase, pectinase, amylase, and protease. In addition, we finally identified clay minerals-derived microorganisms with multi-hydrolytic enzyme activity to secure the microbial sources from domestic clay minerals and consider their applications into bio-industries.

One bentonite and four zeolite samples were respec- tively collected at the Youngil, Gampo and Daebo mining areas located in Gyeongsangbuk-do, Republic of Korea (Table 1). Clay mineral samples were homogenized with distilled water to measure $\mathrm{pH}$ and $\mathrm{NaCl}$ concentration (\%, w/v) by $\mathrm{pH}$ meter (Fisher Science Education, USA) and HI 96821 Refractometer (HANNA instruments, USA), respectively. All of clay mineral samples showed to be the moderately acidic or alkali (6.3-8.1) and $0 \%(\mathrm{w} / \mathrm{v})$ $\mathrm{NaCl}$ concentration (Table 1). Clay mineral samples were crushed and suspended in tryptic soy broth (TSB, Becton, Dickinson and Company, USA) and MRS broth (MRS, KisanBio, Korea) medium. The suspensions were spread onto tryptic soy agar (TSA, Becton, Dickinson and Company, USA) and MRS (KisanBio) and then incubated at $30^{\circ} \mathrm{C}$ for 1 week. After obtaining pure single colonies, genomic DNA of each colony was isolated using HiYield $^{\mathrm{TM}}$ Genomic DNA Mini Kit (RBC, Taiwan). Universal bacterial primer pairs 27F (5'-AGAGTTTGATCMTGGCTCAG-3') and 1492R (5'-TACGGYTACCTTGTTACGACTT-3') were used to amplify 16S rRNA gene for the bacterial identification. The amplified 16S rRNA genes were sequenced by Macrogen sequencing service (Macrogen Inc., Korea) and their sequences then subjected to a homology search against the NCBI database (BLAST) and EzBioCloud (http:// www.ezbiocloud.net/eztaxon/) [14]. After the identification of 262 isolated strains, Pseudarthrobacter sp. (98 species), Bacillus sp. (68 species), Arthrobacter sp. (41 species) and Staphylococcus sp. (36 species) were abundantly isolated from all of clay mineral samples (Fig. 1, Fig. S1). Most of the isolated strains belong to Micrococcales and Bacillales order regardless of the types of clay mineral samples (Table S1). In a previously study about

Table 1. List of domestic clay mineral samples.

\begin{tabular}{|c|c|c|c|c|c|c|}
\hline Sample ID & Mining area & Mineral type & Region & Strains & $\mathrm{pH}$ & $\mathrm{NaCl}(\%)$ \\
\hline Byi33'-b & Youngil-33 & Bentonite & $\begin{array}{l}35^{\circ} 58^{\prime} 7.83^{\prime \prime} \mathrm{N} \\
129^{\circ} 27^{\prime} 5.75^{\prime \prime E}\end{array}$ & 61 & 8.1 & 0 \\
\hline Zgp41-b & Gampo-41 & Zeolite & $\begin{array}{c}35^{\circ} 49^{\prime} 41.47^{\prime \prime} \mathrm{N} \\
129^{\circ} 26^{\prime} 5.15^{\prime \prime} \mathrm{E}\end{array}$ & 45 & 6.6 & 0 \\
\hline Zgp42-b-1 & Gampo-42 & Zeolite & $\begin{array}{l}35^{\circ} 48^{\prime} 57.85^{\prime \prime} \mathrm{N} \\
129^{\circ} 25^{\prime} 28.311^{\prime \prime E}\end{array}$ & 46 & 6.3 & 0 \\
\hline Zgp42-b-2 & Gampo-42 & Zeolite & $\begin{array}{c}35^{\circ} 49^{\prime} 0.79 " \mathrm{~N} \\
129^{\circ} 25^{\prime} 29.99^{\prime \prime} \mathrm{E}\end{array}$ & 50 & 6.9 & 0 \\
\hline Zdb130-b-2 & Daebo-130 & Zeolite & $\begin{array}{l}36^{\circ} 0^{\prime} 58.02^{\prime \prime} \mathrm{N} \\
129^{\circ} 32^{\prime} 2.24^{\prime \prime} \mathrm{E}\end{array}$ & 60 & 7.5 & 0 \\
\hline
\end{tabular}


A: Micrococcaceae

B: Intrasporangiaceae

C: Nocardioidaceae

D: Pseudomonadaceae

F: Paenibacillaceae

\section{G: Bacillaceae}

$\mathrm{H}$ : Staphylococcaceae

I: Flavobacteriaceae

MBBLB1340, MBLB1389, MBBLB1402

Arthrobacter pascens DSM $20545 \mathrm{~T}(\mathrm{XS} 80740)$

MBLB1315, MBLB1348, MBLB1354, MBLB1388, MBLB144

Pseudarthrobacter phenounthrenivorans $\mathrm{Sphe}^{\mathrm{T}}$ (CP002379)

MBLB1334, MBLB1335, MBLB1341, MBLB1345, MBLB1353, MBLL1367, MBLL1369, MBLB1371, MBLB1373, MBLB1379R, MBLB1380, MBLB1381, MBLB1384, MBLB1387, MBLB1392, MBLB1393, MBLB1394, MBBLB1395, MBLB1396, MBLB1397, MBLB1399, MBLB1400, MBBL1401, MBLB1403,

Pseudarthrobacter oxydons DSM $20119^{\mathrm{T}}(\mathrm{X} 83408)$

MBLLB1336, MBBL1337, MBLL1344, MBLB1347, MBLB1349, ,MBLB1351, MBLB1352, MBLB1355, MBLB1356, MBLB1357, MBLB1358, MBLB1360,

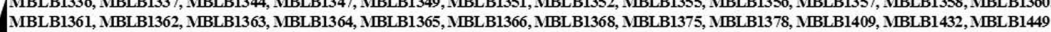
Pseudarthrobacter siccitolerans $4527^{\mathrm{T}}$ (CAQ101000001)

MBBLB1338, MBLB1372, KIGAV035

Pseudarthobacter defluvii $4 \mathrm{Cl}_{-\mathrm{a}} \mathrm{a}^{\mathrm{T}}$ (AM 409361$)$

MBLB1350, MBRLB1374, MBLB1376, MBLB1398, MBLB1438, MBLB1440

Pseudarthrobacter sulfonivorans ALLT (AF235091)

99 MBLB1428

Arthrobacter pokkralii $\mathrm{P} 3 \mathrm{~B} 162^{\mathrm{T}}$ (KM507333)

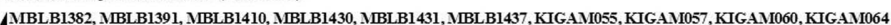

Arthrobacter oryzae KV-651 $\left.\mathrm{T}^{\mathrm{T}} \mathrm{AB} 279889\right)$

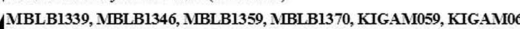

Arthrobacter humicola $\mathrm{KV}-653^{\mathrm{T}}$ (AB2798990)

MBLB1455, MBLB1457, KIGAM071, KIGAM075, KIGAM0078, KIGAM080R, KIGAM081, KIGAM084, KIGAM089R, KIGAM090, KIGAM091

Arthrobacter nitrophenolicus $\mathrm{SJC}_{\mathrm{C}} \mathrm{T}$ (AOFD01000111)

97 MBLB1406, MBBLB1407, MBLB1427, MBLB1429, MBLB1435, MBLLB1450, MBLB1451, MBLB1452, MBLB1453, MBLLB1456, MBLB1459,

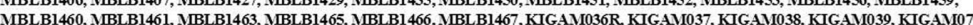

KIGAM079, KIGAM083

Pseudarthrobacter niigatensis LC4 ${ }^{\mathrm{T}}$ (AB248526)

MBLBI426, MIBLB1454, MBLB1462, MBLB1464, KIGAM073, KIGAM074, KIGAM076, KIGAM077, KIGAM082

Arthrobacter enclensis NTO-1008T (FF421614)

Arthrobacter ginsengisoli $\mathrm{DCY}{ }^{\mathrm{T}} \mathrm{T}(\mathrm{KF} 212463)$

Micrococcus yumanensis YIM $65004^{\mathrm{T}}$ ( $\left.\mathrm{FJ} 214355\right)$

99 KIGAM085, KIGAM086, KIGAM087, KIGAM088

Phycicoccus aerophilus 5516T-20T (EF 493847)

100 MBLB1383, MBLB1385, MBLB1386, MBLB1445, MBLB1446, MBLB1447,,MBLB1474 Nocardioides loibbensis KSL- $2^{\mathrm{T}}$ (AY835924)

100 MBLB1470, MBRLB1471, MBBLB1472, MBLB1473

100 Pseudomonos frederiks bergensis JAJ28 ${ }^{\mathrm{T}}$ (AJ249382)

MBLLB1316, MBLB1390

100 Paenibacillus glucanolyticus DSM 5162 ${ }^{\mathrm{T}}$ (AB073189)

MBLB1469

KIGAM012, KIGAM014

KIGAM013, KIGAM015

Bacillus aryabhatai $\mathrm{B} 8 \mathrm{~W} 22^{\mathrm{T}}$ (EF114313)

Bacillus flexus NBRC 15715 T (BCVD01000224)

MBLB1413, MBBLB1414, MBBLB1415, MBBLB1416, MBLB1417, MBBLB1418, MBLB1 420, MBLB1421, MBBLB1425, MBLB1434, KIGAV1022, KIGAM069

94 Bacillus paralicheniformis $\mathrm{KJ}-16^{\mathrm{T}}$ (KY694465)

MBLB1419, MBRLB1422, MBBLB1423,MBLB1424, MBBLB1433, MBBLB1458

Staphylococcus epidermidis ATCC $14990^{\mathrm{T}}$ (L37605)

-KIGAM016, KIGAM023, KIGAM024, KIGAM029, KIGAM030, KIGAM031, KIGAM056, KIGAM058, KIGAM061, KIGAM062 KIGAM040

lococcus capitis subsp. capitis ATCC 27840 (L37599)

MGA 0006, KIGAM007, KIGAM008, KIGAM009, KIGAM010, KIGAM011, KIGAM027, KIGAM028, KIGAM041, KIGAV042, KIGAM043,

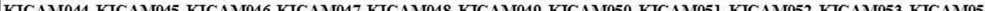

KIGAM065, KIGAM066, KIGAM068

Staphylococcus wameri ATCC $27836^{\mathrm{T}}$ (L37603)

Bacillus toyonensis BCT-7112 ${ }^{\mathrm{T}}$ (CP006863)

KIGAM004, KIGAM019, KIGAM020, KIGAM025, KIGAM02

Bacillus luti TD41 (MACI01000041)

KIGAM001,KIGAM005, KIGAM018, KIGAM021, KIGAM034, KIGAM070

Bacillus mobilis 0711P9-1 ${ }^{\mathrm{T}}$ (MACF01000036)

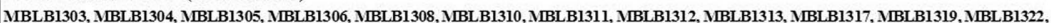

MBLB1323, MBLB1328, , MBLB1329, MBLB1330, MBLB1331, MBLB1332, MBRLB1342, MBLB1343

Bacillus pacificus $\mathrm{EB} 422^{\mathrm{T}}(\mathrm{KJ} 812450)$

MBLB1327

Bacillus albus $\mathrm{N} 35-10-2^{\mathrm{T}}$ (MAOE01000087)

MBLB1307, MBLB1309, MBLB1314, MBLB1318, MBLL1320, MBLB1324, MBLLB1325, MBLB1326, KIGAM002, KIGAM003, KIGAM017, KIGAM032, KIGAM033

Bacillus cereus ATCC 14579T (AE016877)

0.05

$\left.{ }_{100}^{\text {Chryseobaci }}\right|_{\text {MBLB1333 }}$

Level

Fig. 1. Neighbor-joining (NJ) phylogenetic tree based on $16 \mathrm{~S}$ rRNA gene sequences showing the position and relationship of strains isolated from domestic bentonite and zeolite samples and other related taxa. The evolutionary distances were calculated using the Kimura two-parameter model. Numbers at nodes indicate bootstrap values ( $>70 \%)$ calculated based on the NJ. Bar, 0.05 substitutions per nucleotide position. Micrococcaceae (A), Intrasporangiaceae (B), Nocardioidaceae (C), Pseudomonadaceae (D), Paenibacillaceae (F), Bacillaceae (G), Staphylococcaceae (H), and Flavobacteriaceae (I) represent family level. 
culture-dependent microbial diversity of two bentonite samples, isolates belonging to the three phyla Proteobacteria, Actinobacteria, and Firmicutes were reported [15]. Similar microbial clusters were identified in zeolites collected in the Gampo area. P. oxydans was the most distributed among the Pseudarthrobacter sp. belong to the phylum Actinobacteria in the bentonite and zeolite. Researchers were reported that the Pseudarthrobacter sp. was isolated in the soil [16]. The genus Bacillus sp. belong to the phylum Firmicutes was the largest proportion of microorganisms in the clay mineral samples, Byi33'-b and Zdb130-b-2, in which B. mobilis, B. glycinifermentans, and $B$. albus were the most distributed. B. mobilis and B. albus are spore-forming and facultative anaerobic bacteria with being distributed in various environments [17]. Generally, Bacillus sp. was isolated from soil and $B$. thuringiensis was most plentiful in soil samples from Asia [18]. A. nitrophenolicus, A. oryzae, and $A$. enclensis were mainly isolated among the strains of the genus Arthrobacter within the phylum Actinobacteria which were widely distributed in all of clay minerals. S. warneri was the most abundant among the genus Staphylococcus sp. isolated from only Zgp-41-b, Zgp42-b2, and Zdb130-b-2 samples. As the isolates with minor proportion, $P$. frederiksbergensis and C. rhizosphaerae were isolated from only bentonite sample Byi33'-b. Taken together with previous studies, our results showed a high microbial diversity in bentonite and zeolite samples, dominated by bacterial phyla Firmicutes and Actinobacteria [15, 19, 20].

Cultivable isolation of diverse microorganisms from clay minerals triggered the investigation of industrial enzyme productions to promote the industrial application of clay minerals-derived functional microorganisms. We investigated the hydrolytic enzyme activities of the isolated strains from clay minerals. First-round screening of $\alpha$-amylase, 262 isolates were plated on starch agar (TSB with $0.2 \%(\mathrm{w} / \mathrm{v})$ soluble starch) and incubated at $30^{\circ} \mathrm{C}$ for $48 \mathrm{~h}$. The plates were then stained by Lugol's iodine solution to monitor a halo zone around the colonies. On the other hand, carboxymethyl cellulose (CMC) agar plate (TSB with 1.0\% (w/v) CMC) was used to screen the cellulase activity, followed by the incubation at $37^{\circ} \mathrm{C}$ for $72 \mathrm{~h}$. Thereafter, the plates were stained with $0.1 \%(\mathrm{w} / \mathrm{v})$ congo red solution for $15 \mathrm{~min}$ and destained by $1 \mathrm{M} \mathrm{NaCl}$ for $1 \mathrm{~h}$ to detect a halo zone. Skim milk agar plate (TSA

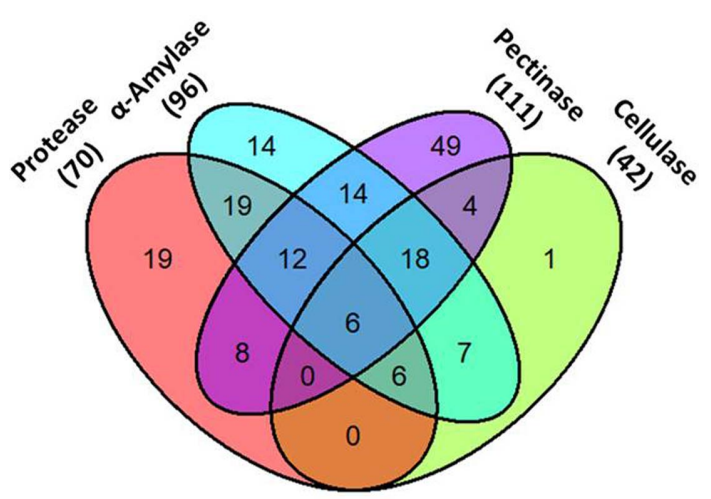

Fig. 2. Venn diagram representing the number of hydrolytic enzymes-producing microorganisms isolated from clay mineral samples. Numbers in brackets indicate the numbers of isolates showing each of hydrolytic enzyme activities.

containing with $1 \%(\mathrm{w} / \mathrm{v})$ skim milk) was also employed to screen protease-producing bacteria. The isolates were incubated on skim milk agar plates at $30^{\circ} \mathrm{C}$ for $48 \mathrm{~h}$ to indicate protease production as showing a halo zone. As the results, $\alpha$-amylase activity was indicated in 96 strains, whereas cellulase and protease activities were detected in 42 and 70 strains, respectively (Fig. 2). Quantifications of $\alpha$-amylase, cellulase, and pectinase activity were evaluated by the modified method of DNS (3,5-dinitrosalicylic acid) assay [20], while protease activity was tested by simply modified Lowry method [21]. The positive hydrolytic strains were cultivated Nutrient Broth with 0.5\% (w/v) starch, Luria-Bertani broth with $1 \%(\mathrm{w} / \mathrm{v}) \mathrm{CMC}$ and $0.5 \%(\mathrm{w} / \mathrm{v})$ pectin, or TSB for $48 \mathrm{~h}$ at $37^{\circ} \mathrm{C}$. To obtain a crude enzyme solution, the cultures were centrifuged (13,000 rpm, $\left.15 \mathrm{~min}, 4^{\circ} \mathrm{C}\right)$, following the collection of supernatants. The reactions for $\alpha$-amylase, cellulase and protease were performed as described by Seo et al. [20]. To measure the quantification of pectinase activity, the enzyme reaction was carried out in $200 \mu \mathrm{l}$ reaction mixture containing $0.5 \%$ (w/v) polygalacturonic acid in $50 \mathrm{mM}$ sodium acetate buffer (pH 5.0), and $100 \mu \mathrm{l}$ crude enzyme. After enzyme reaction in water bath for $30 \mathrm{~min}$ at $50^{\circ} \mathrm{C}$, the enzyme activity was measured by the modified method of DNS method.

$\alpha$-Amylase activity over $0.2 \mathrm{U} / \mathrm{ml}$ was detected in only 38 strains of which majority was from Byi33'-b sample (Fig. 3A). In particular, B. cereus MBLB1321 and B. mobilis MBLB1328, of which both are isolated from 

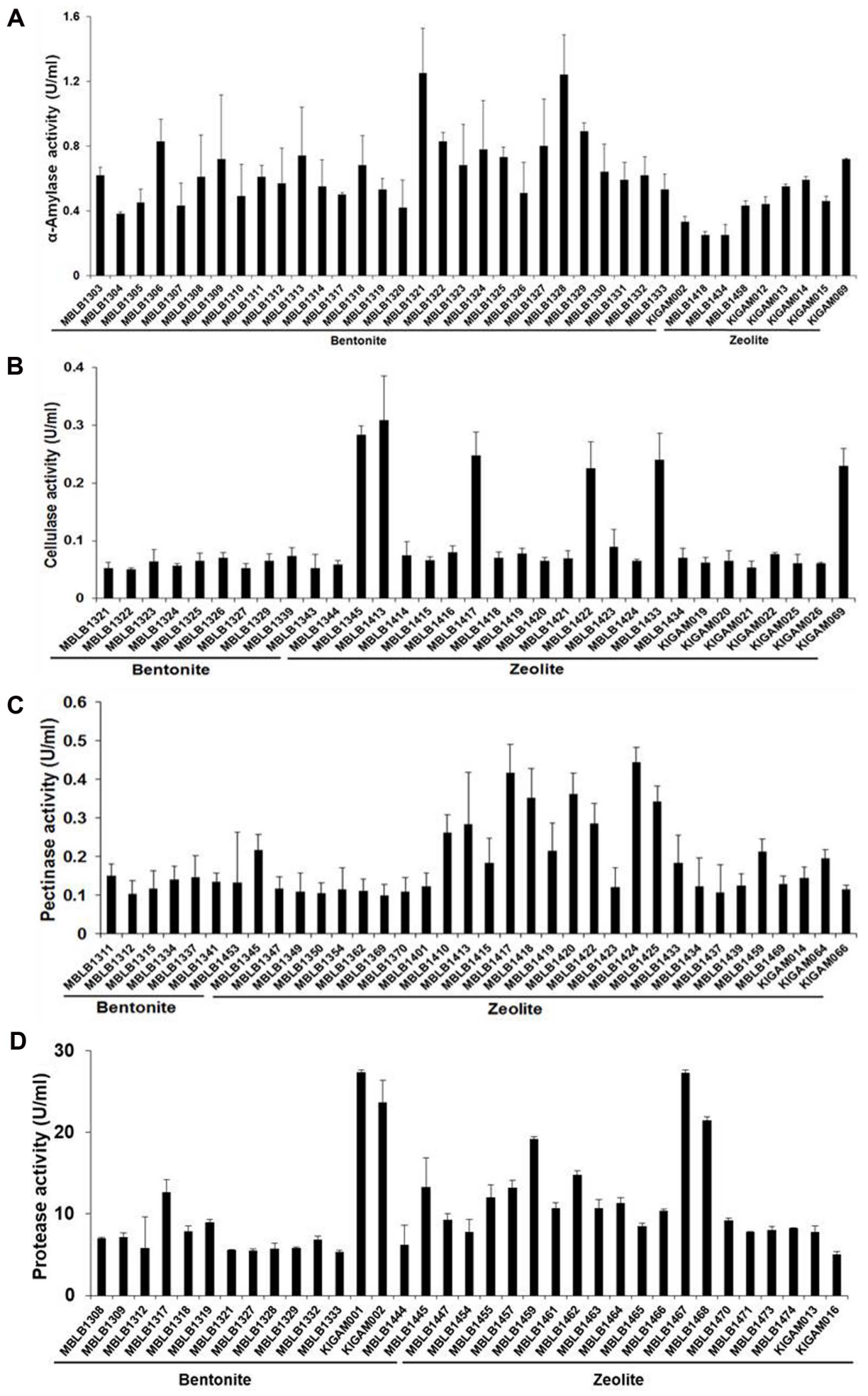

Fig. 3. Hydrolytic enzyme activities including $\alpha$-amylase (A), cellulase (B), pectinase (C), and protease (D) of the strains isolated from clay mineral samples. One unit of $\alpha$-amylase and cellulase activities were defined as the amount of enzyme which releases $1 \mu$ mole of D-glucose per min from starch and CMC, respectively. One unit of pectinase activity was defined as the amount of enzyme which releases $1 \mu$ mole of D-galacturonic acid per min from polygalacturonic acid under experimental conditions. One unit of protease activity was defined as the amount of enzyme which releases $1 \mu \mathrm{g}$ of tyrosine per min from casein. 
Byi33'-b bentonite sample, exhibited the highest $\alpha$ amylase activity, 1.25 and $1.24 \mathrm{U} / \mathrm{ml}$, respectively. In previous studies, B. licheniformis Shahed-07 and $B$. subtilis ISOLATE-4 isolated from soil was reported to produce $\alpha$-amylases [22, 23], and B. macerans SBM1 and SBM2 strains had $\alpha$-amylase activities ranging from 0.12 to $1.30 \mathrm{U} / \mathrm{ml}$, similar to that of B. cereus MBLB1321 and B. mobilis MBLB1328 [24]. Cellulase production over $0.05 \mathrm{U} / \mathrm{ml}$ of enzyme activity was detected in 33 strains, among which B. glycinifermentans MBLB1413 from Zdb130-b-2, P. oxydans MBLB1345 from Zgp41-b, and B. glycinifermentans MBLB1417 from Zdb130-b-2 showed 0.31, 0.28, and $0.25 \mathrm{U} / \mathrm{ml}$, respectively (Fig. 3B). There are many reports on the cellulase productions from bacterial isolates from soil samples; e.g. B. amyloliquefaciens DL-3 and B. licheniformis CDB-12 [25, 26]. Our previous study also reported that 30 strains isolated from bentonite samples showed cellulase activity, including B. tequilensis MBLB1223 and B. siamensis MBLB1268 [20]. Pectinase responsible for the degradation of pectin polysaccharides are industrially useful enzyme for the clarification, extraction and concentration of tea and juice as well as textile fibre production [27]. We screened 36 strains exhibiting the pectinase activity over $0.1 \mathrm{U} / \mathrm{ml}$ from clay mineral samples (Fig. $3 \mathrm{C})$. Almost of these strains were isolated from Zdb130b-2 zeolite sample, in which B. paralicheniformis MBLB1424 and B. glycinifermentans MBLB1417 were found to produce the highest pectinase activity, 0.44 and $0.42 \mathrm{U} / \mathrm{ml}$, respectively. Similar with our study, several studies reported diverse microbial strains producing pectinase; e.g. B. subtilis CR-179 isolated from a subtropical forest soil and Bacillus sp. DCU27 isolated from wet land soil [28, 29]. Finally, we re-isolated 35 strains showing protease activity over $5.0 \mathrm{U} / \mathrm{ml}$ of enzyme activity from clay mineral samples (Fig. 3D). Among them, protease activities of $B$. luti KIGAM001 isolated from bentonite sample Byi33'-b and P. niigatensis MBLB1467 from zeolite sample Zdb130-b-2 were 27.37 and $27.33 \mathrm{U} /$ $\mathrm{ml}$, respectively. The commercially used proteases are mostly produced by Bacillus sp., and the activity of proteases is powerful [30]. Some studies have been done for screening isolates, derived from soil, for proteolytic enzyme production. Protease-producing B. infantis SKS1 isolated from garden soil showed thermostable characteristic [31] and B. thuringiensis 2.3PT3 isolated from Thailand soil had protease activity with $3.72 \mathrm{U} / \mathrm{mg}$ [32].

Taken together, 177 bacterial isolates from clay mineral samples showed one or more hydrolytic enzymes. In particular, 6 strains (B. cereus MBLB1321, B. albus MBLB1326, B. mobilis MBLB1328, B. mobilis MBLB1329, B. mobilis MBLB1330, and B. albus KIGAM017) were proved to be efficient producers of all four type enzymes and thus could be considered to have high biotechnological potential (Fig. 2). We deposited gene sequences of the B. cereus MBLB1321, B. albus MBLB1326, B. mobilis MBLB1328, B. mobilis MBLB1329, B. mobilis MBLB1330, and B. albus KIGAM017 in GenBank/EMBL/DDBJ under the accession numbers MK280734, MK280736, MK280735, MK280737, MK280738, and MK280739 for 16S rRNA genes of multi-hydrolytic enzyme-producing bacteria. There are several studies reporting on the isolation of microorganisms with multi-hydrolytic enzyme activities, such as B. subtilis SR60 isolated from coral reefs showing amylase, cellulase, xylanase, and protease activities [33] and B. subtilis CR-179 from subtropical forest with esterase, cellulase, pectinase, xylanase, and lipase enzyme activities [28].

In conclusion, the diverse members of Micrococcales and Bacillales order were isolated from clay minerals, zeolite and bentonite, which were collected at domestic mining areas in Gyeongsangbuk-do, Republic of Korea. Total 262 isolates were also evaluated to determine the hydrolytic enzyme production including $\alpha$-amylase, cellulase, pectinase, and protease. Among the 177 isolates exhibiting one or more hydrolytic enzyme activities after evaluation of all isolates, we finally isolated $B$. cereus MBLB1321, B. albus MBLB1326 and KIGAM017, B. mobilis MBLB1328, MBLB1329 and MBLB1330 showing all the hydrolytic enzyme activities. These findings suggest the increase of attention of domestic clay minerals due to the potential of the diverse presence of functional microorganisms producing hydrolytic enzymes which may be used to serve various bio-industrial purposes.

\section{Acknowledgments}

This research was supported by the Basic Research Project of the Korea Institute of Geoscience and Mineral Resources (KIGAM) funded by the Ministry of Science and ICT. This research was also supported by Collaborative Research Program of the Korea Food Research Institute (KFRI) funded by the Korea Institute of Geoscience and Mineral 
Resources (KIGAM). This study was also supported by the National Research Foundation of Korea (NRF) grant funded by the Korea government (MIST) (NRF-2019R1A2C1006038).

\section{Conflict of Interest}

The authors have no financial conflicts of interest to declare.

\section{References}

1. Carretero MI. 2002. Clay minerals and their beneficial effects upon human health. A review. Appl. Clay Sci. 21: 155-163.

2. Murray HH. 2000. Traditional and new applications for kaolin, smectite, and palygorskite: A general overview. Appl. Clay Sci. 17: 207-221.

3. Barton CD, Karathanasis AD. 2002. Clay minerals, pp. 187-192. In Lal R (ed.), Encyclopedia of Soil Science, 2nd Ed. Marcel Dekker, New York.

4. Guggenheim S, Martin R. 1995. Definition of clay and clay mineral: joint report of the AIPEA nomenclature and CMS nomenclature committees. Clay. Clay Miner. 43: 255-256.

5. Slamova R, Trckova M, Vondruskova H, Zraly Z, Pavlik I. 2011. Clay minerals in animal nutrition. Appl. Clay Sci. 51: 395-398.

6. Rožić M, Cerjan-Stefanović Š, Kurajica S, Vančina V, Hodžić E. 2000. Ammoniacal nitrogen removal from water by treatment with clays and zeolites. Water Res. 34: 3675-3681.

7. Eroglu N, Emekci M, Athanassiou CG. 2017. Applications of natural zeolites on agriculture and food production. J. Sci. Food Agric. 97: 3487-3499.

8. Al Dwairi RA, Al-Rawajfeh AE. 2012. Recent patents of natural zeolites applications in environment, agriculture and pharmaceutical industry. Recent Patents Chem. Eng. 5: 20-27.

9. Saengmee-anupharb S, Srikhirin T, Thaweboon B, Thaweboon S, Amornsakchai T, Dechkunakorn S, et al. 2013. Antimicrobial effects of silver zeolite, silver zirconium phosphate silicate and silver zirconium phosphate against oral microorganisms. Asian Pac. J. Trop. Biomed. 3: 47-52.

10. SivaRaman H, Chandwadkar A, Baliga SA, Prabhune AA. 1994. Effect of synthetic zeolite on ethanolic fermentation of sugarcane molasses. Enzyme Microb. Technol. 16: 719-722.

11. Uddin F. 2018. Montmorillonite: An Introduction to Properties and Utilization, pp. 3-23. In Zoveidavianpoor M (ed.), Current Topics in the Utilization of Clay in Industrial and Medical Applications, IntechOpen, London.

12. Kang J, Chung WH, Nam Y Do, Kim D, Seo SM, Lim S Il, et al. 2018. Impact of clay minerals on bacterial diversity during the fermentation process of kimchi. Appl. Clay Sci. 154: 64-72.

13. Mueller B. 2015. Experimental interactions between clay minerals and bacteria: A Review. Pedosphere 25: 799-810.

14. Yoon SH, Ha SM, Kwon S, Lim J, Kim Y, Seo H, et al. 2017. Introducing EzBioCloud: A taxonomically united database of $16 \mathrm{~S}$ rRNA gene sequences and whole-genome assemblies. Int. J. Syst. Evol.
Microbiol. 67: 1613-1617.

15. López-Fernández M, Fernández-Sanfrancisco O, Moreno-García A, Martín-Sánchez I, Sánchez-Castro I, Merroun ML. 2014. Microbial communities in bentonite formations and their interactions with uranium. Appl. Geochem. 49: 77-86.

16. Busse HJ. 2016. Review of the taxonomy of the genus Arthrobacter, emendation of the genus Arthrobacter sensu lato, proposal to reclassify selected species of the genus Arthrobacter in the novel genera Glutamicibacter gen. Nov., Paeniglutamicibacter gen. nov., Pseudoglutamicibacter gen. nov., Paenarthrobacter gen. nov. and Pseudarthrobacter gen. nov., and emended description of Arthrobacter roseus. Int. J. Syst. Evol. Microbiol. 66: 9-37.

17. Liu Y, Du J, Lai Q, Zeng R, Ye D, Xu J, Shao Z. 2017. Proposal of nine novel species of the Bacillus cereus group. Int. J. Syst. Evol. Microbiol. 67: 2499-2508.

18. Martin PA, Travers RS. 1989. Worldwide abundance and distribution of Bacillus thuringiensis isolates. Appl. Environ. Microbiol. 55: 2437-2442.

19. Eppard M, Krumbein WE, Koch C, Rhiel E, Staley JT, Stackebrandt E. 1996. Morphological, physiological, and molecular characterization of actinomycetes isolated from dry soil, rocks, and monument surfaces. Arch. Microbiol. 166: 12-22.

20. Seo DH, Cho ES, Hwang CY, Yoon DJ, Chun J, Jang Y, et al. 2019. Cultivable microbial diversity in domestic bentonites and their hydrolytic enzyme production. Microbiol. Biotechnol. Lett. 47: 125-131.

21. Li DF, Ding HC, Zhou T. 2013. Covalent immobilization of mixed proteases, trypsin and chymotrypsin, onto modified polyvinyl chloride microspheres. J. Agric. Food Chem. 61: 10447-10453.

22. Rasooli I, Astaneh SDA, Borna H, Barchini KA. 2008. A thermostable $\alpha$-amylase producing natural variant of Bacillus spp. isolated from soil in Iran. Am. J. Agric. Biol. Sci. 3: 591-596.

23. Kalyani G, Rajesh EM. 2018. Production and purification of amylase from Bacillus subtilis isolated from soil. Int. J. Eng. Manag. Res. 8: $246-254$.

24. O AA, Fagade OE. 2006. Growth pattern and structural nature of amylases produced by some Bacillus species in starchy substrates. Afr. J. Biotechnol. 5: 440-444.

25. Lee YJ, Kim BK, Lee BH, Jo KI, Lee NK, Chung CH, et al. 2008. Purification and characterization of cellulase produced by Bacillus amyoliquefaciens DL-3 utilizing rice hull. Bioresour. Technol. 99: 378-386.

26. Behera BC, Mishra RR, Singh SK, Dutta SK, Thatoi H. 2016. Cellulase from Bacillus licheniformis and Brucella sp. isolated from mangrove soils of Mahanadi river delta, Odisha, India. Biocatal. Biotransformation 34: 44-53.

27. Kashyap DR, Vohra PK, Chopra S, Tewari R. 2001. Applications of pectinases in the commercial sector: a review. Bioresour. Technol. 77: 215-227.

28. Ruiz C, Pastor FIJ, Diaz P. 2005. Isolation of lipid- and polysaccharide-degrading micro-organisms from subtropical forest soil, and analysis of lipolytic strain Bacillus sp. CR-179. Lett. Appl. Microbiol. 40: 218-227. 
29. Ghosh A, Maity B, Chakrabarti K, Chattopadhyay D. 2007. Bacterial diversity of east Calcutta wet land area: possible identification of potential bacterial population for different biotechnological uses. Microb. Ecol. 54: 452-459.

30. Bhunia B, Basak B, Dey A. 2012. A review on production of serine alkaline protease by Bacillus spp. J. Biochem. Technol. 3: 448-457.

31. Saggu SK, Mishra PC. 2017. Characterization of thermostable alkaline proteases from Bacillus infantis SKS1 isolated from garden soil. PLoS One 12: e0188724.
32. Luang-In V, Yotchaisarn $M$, Saengha W, Udomwong $P$, Deeseenthum S, Maneewan K. 2019. Protease-producing bacteria from soil in nasinuan community forest, mahasarakham province, Thailand. Biomed. Pharmacol. J. 12: 587-595.

33. de Veras BO, dos Santos YQ, Diniz KM, Carelli GSC, dos Santos EA. 2018. Screening of protease, cellulase, amylase and xylanase from the salt-tolerant and thermostable marine Bacillus subtilis strain SR60. F1000Res 7: 1704. 